\title{
THE ETHNO-BOTANY AND UTILITY EVALUATION OF SOME SPECIES OF CUCURBITS AMONG THE PEOPLE OF NIGER DELTA NIGERIA
}

\author{
N. L. EDWIN-WOSU, AND B. C. NDUKWU
}

(Received 8, March 2007; Revision Accepted 14, August 2007)

\begin{abstract}
Cucurbits are known to occupy a prominent position in the life and culture of many ethnic groups in the Niger Delta. Field observation has shown that every farming family (e.g. In Rivers State) has at least one cucurbit species in its garden. Beside the range of species already in cultivation, many more species are known to occur in the wild (at least six of such species) with their nutritional potential and other uses apparently unknown. There is the need to develop accurate data, and to put in place more effort toward the cultivation, improvement and conservation of various cucurbits germplasm. An inventory was canned out to track down and document the ethnobotanical uses of the various species of cucurbits found in the Niger Delta areas of Nigeria. The study recorded 15 (fifteen) species distributed into eleven genera in the ecozone. A number of the species are found to have established cultivars as in Lagenaria siceraria. The various species were also observed to be utilized for different purposes by the indigenous people of the Niger Delta.
\end{abstract}

KEYWORDS: Niger Delta, Cucurbits, Ethnobotany, Germplasm.

\section{INTRODUCTION}

The word 'Ethno' means the way people see the world. When used as a prefix to an academic discipline such as botany or pharmacology, then it entails exploring the ordinary man's (native of an environment) perception of cultural, natural or scientific knowledge (Martin, 1995). It is increasingly becoming an important aspect of plant science. This is particularly so due to the global drive towards the documentation of customary use and knowledge of plants (Cunningham, 1994). The Cucurbit is a plant family of medium -sized prostrate runner, primarily found in the Warmer regions of the world, and a major family of economically important species, particularly those with edible fruits. Some of these represent part of the earliest cultivated plants in both the old and new worlds. Some have medicinal and other uses. The family is morphologically and biochemically distinct from other families and has been considered a monophyletic. It is phylogenetically considered a closest ally to Begoniaceae in the order violales.

The Cucurbit is a family of about 100 to 130 genera and over 750 to 900 species globally (Jeffrey, 1964 and 1980; Yamaguchi, 1983). A number of species have been reported in Nigeria, of which 21 genera and 41 species are represented (Hutchinson and Dalziel, 1954; Okoli 1984; Ibiok et al 1991, Ndukwu, 2000), and 15 species of 11 genera are represented in the Niger Delta. These include cultivated and wild species. Among the cultivated genera in the Niger Delta are Citrullus, Telfairea, Cucurbita, Cucumeropsis, Lagenaria, Cucumis, and Trichosanthes. While Telfairea is cultivated for its leaves and seeds, Cucurbita for its leaves and fruits, others are cultivated for their fruits and /or seeds. The wild genera in the area include Luffa, Lagenaria, Coccina, Momordica and Zehneria (Edwin - wosu, 2005).

Several taxonomic studies have been carried out on some species of Cucurbit found in Nigeria but there has not been sufficient ethnobotanical information with those particularly found in the Niger Delta areas. This present study is aimed at bridging this information gap with the objective of tracking and documenting the ethnobotanical uses of the various species of Cucurbits found in the Niger Delta. Besides the need to develop accurate data, more efforts are needed toward the cultivation, improvement and conservation of the various cucurbits germplasms.

\section{MATERIALS AND METHODS}

\section{Geographical Description of the Study Area:}

Cartographically the Niger Delta is the Southern segment of Nigeria, which implies areas supplied with water from the Rivers Niger and Benue as they flow together after Lokoja (the confluence) to empty their contents in the Atlanic Ocean. These rivers (now joined) broke up at Abor into the Rivers Nun and Forcados (including their tributaries). The Niger Delta proper is thus that portion of the land mass (including water) traversed by the Rivers Nun and Forcados (including their tributaries). The portion of the Niger Delta traversed by the River Nun is the present Bayelsa State, while the present Delta State is being traversed by the River Forcados. The Nun River Broke up into many Rivers and creeks such as Santa Barbara, St. Nicholas, Brass, Nun, Sangana, Fishtown, Koluama, Middleton, Digatoru, Pennington, Dodo and Ramos Rivers, which empty into the Atlantic Ocean, (Alagoa, 1999).

The Niger Delta in sensu-stricto has also been seen from the ecological perspective as that portion of the southern Nigeria stemming from a northern apex situated at Aboh, with the Imo River bounding the eastern periphery and Benin river bounding the western periphery and on the south by the Atlantic Ocean (Fubara et al, 1988). It is the Africa's largest Delta covering some 70,000 square kilometers $\left(\mathrm{km}^{2}\right)$, of which one third of the area is made up of wetland (Afolabi, 1998). The Niger Delta area covered in this study extends from latitude $4^{\circ} 30^{1} \mathrm{~N}$ and $8^{\circ} \mathrm{N}$ and Longitude $4^{\circ} \mathrm{E}$ and $8^{\circ} 45^{1} \mathrm{E}$. It includes parts of Rivers, Delta, Bayelsa, Edo, Akwa-lbom, and Cross River States. Others are parts of Abia, Imo and Ondo States. The area is generally tropical, thus its climatic regimes exhibit extremes of temperature, (in view of the latitudinal location of the states in the equatorial belt, resulting to high temperature being recorded all year round). Seasonal and latitudinal variations affect the extremes of recorded temperature, diurnal and seasonal ranges, relative humidity,

\footnotetext{
N. L. Edwin-Wosu, Department of Plant Science and Biotechnology, University of Port Harcourt, Choba, P.M.B. 5323 Port Harcourt Rivers State, Nigeria

B. C. Ndukwu Department of Plant Science and Biotechnology, University of Port Harcourt, Choba, P.M.B. 5323 Port Harcourt Rivers State, Nigeria
} 
which is comparatively uniform due to the proximity of the region to the Atlantic Ocean. The area is also associated with a relatively high rainfall pattern (Alagoa, 1999). Though the area is of high tropical rainforest vegetation, but characterized by coastal ridge barriers, mangroves fresh water swamp and lowland rainforest, which are attributes of a large river delta in a tropical region (Teme, 2001) (see study map).

\section{Species Ethno-Assessment}

The study involving extensive field trips in parts of the Niger Delta started in December 2004. During the field trips collections were made of life specimens either in cultivation or in the wild. Specimens, which could not be readily collected, were purchased from local markets where they were displayed for sale. Attempts were made to identify the specimens to species level at collections. Those that could not be readily identified were later identified with the aid of reference books and Floras such as Flora of West Tropical Africa (Hutchinson and Dalziel, 1954); and Useful Plant of West Tropical Africa (Burkill, 1985). Oral interviews and guided questionnaires were administered to older members and key informants of the local communities in parts of the study areas where collection were made to assess the ethnobotanical values of 15 species of 11 genera of the Cucurbits observed. A randomized field sampling strategy of 10 people (key informant representative of the people in the communities of the study areas) was engaged and their response and recorded information used to ascertain the various uses of the plants within the areas. Market observations particularly targeting the various utilities of these plants were also carried out.

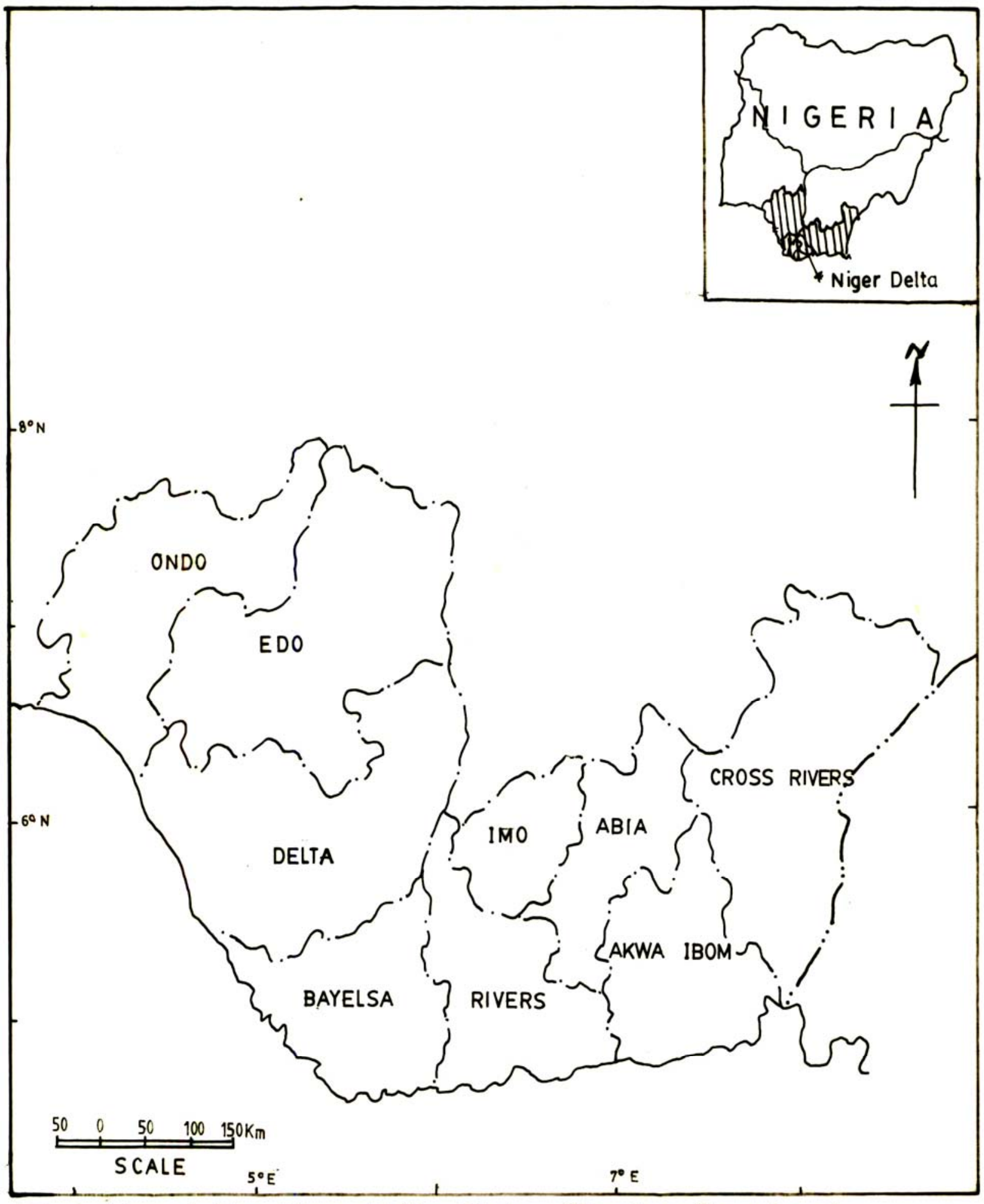

Fig. 1 Map of the Niger Delta States Showing Sample Area 


\section{RESULTS}

Trichosanthes cucumerina Linn: In various parts of Niger Delta the fruit serves as vegetable, while the bright red pulp around the mature seed is extracted and either mixed with Lycopersicon esculentum P. Mill. or used alone in cooking categories of food.

Lagenaria guineensis (G.Don) C. Jeffreyobservation by participatory rural appraisal had shown that the fruit is a popular "foot ball" among the boys in the rural areas. The fruit is used as a cathartic for cleansing and purgative. The fruit juice is used together with dye of wood ash to remove hair from hides. The leaves are fed with relish to rabbits and related animals.

Momordica charantia Linn: In some parts of Niger Delta area (particularly in Ikwerre and Emuoaha axis in Rivers State) the fruit of the plant is used for snake poison.

Citrullus vulgaris (Linn) Schrad - commonly used as a food additive, to thicken soup by the people of the area.

Luffa aegyptiaca Miller, in the various parts of Niger Delta (e.g. in Itu, Ikot Abasi and Ekannufon in Akwa Ibom State; Elele, Igwurruta, Ubima, in Ikwerre, Rivers State; Ukwa West, Asa and Obehie in Abia State) the dry mesocarp of the fruit is used as sponge for dry cleaners and washer men for both bathing and washing clothing materials. Field observation has shown that Palm-wine tapers in these afformentioned areas of Niger Delta involved in wine production use the mesocarp as filters. So also as car oil filters in Ore Ondo State and marine engine filters by some people in Rivers State. Also in areas involved in farming, these dry fibres are used for setting bush fire.

Cucumis sativus Linn. In various parts of Niger Delta, the immature green fruits are eaten fresh and as rich source of vitamins and minerals (vit. B \& C, iron and calcium) respectively,it is a neutralizer of stomach acidity, and used as mouth washing agent among the people of Niger Delta.

Lagenaria siceraria (Molina) Standley. This species is various varieties and are used for various purposes in the Niger Delta area. The Seeds are used as melon seed for cooking in some areas. The dry guard is used in water storage for farm and home use, as well as in grain and cereal storage. It is also used for dried crayfish storage in riverine areas. The cup shaped variety is used for drinking in official and non official ceremonies in areas like Akwa Ibom; Ikwerre, Obio / Akpor, Emuoha in Rivers State; Abia and Imo States, while the flute shaped type is used as musical instrument and the base fragment used for garri processing (e.g. in Ikwerre, Rivers State. It is also used for rituals and oat taking as could be observed in some farm roads, where they serve as drinking water gourd for the gods and their appease in areas like Kira, Sime and Barayira in Tai Local Government Area of Rivers State. It is used to administer enema for both children and adult in some of the areas and also in areas like Ikwerre for preserving pounded cocoyam and foo-foo, which makes them hot for very many hours than the metallic plates. Also it serves as wine funnel and jug and as a horn is uta play in Akwa-lbom State of Nigeria.

Telfairea occidentalis Hooker Fill. is cultivated in various parts of the Niger Delta for their palatable leaves and nutritious seeds used in the preparation of various forms of food. The leaves and tender stems are a delicacy in these areas of study. They are used to prepare mouth-watering native soups particularly in Ikwerre villages in Rivers State. The leaves and tender shoots form good accompaniments when yams, cocoyam, sweet yams and plantains are cooked. The seeds are edible after cooking; they are also ground and put into soups as thickener. The seeds can be scaled, shelled and dried for future use. The leaves and tender stems are taken as fodder by goats; sheep etc edible oil is extracted from the seeds. Leaf extract, pure or mixed with eggs, is drunk to treat anaemia. The leaves and those of garden eggs squeezed and drunk for seven days also eradicate anaemia thus enhance the formation of red blood cells. The old stem are beaten, washed and dried to produce batting or washing sponge. The seeds are fermented, crushed into a mash and used to prepare a popular native source called "Oton", which is used to eat boiled or roasted yams, plantain, sweet yams, cocoyam corns, aerial yam, and sweet cassava. The fruit pod and endocarp are used to feed snails.

Cucurbita moschata (Duch ex.Lam)ex poiret. In areas where it is cultivated, the leaf serves as an important vegetable together with the fruit, whose pulp is eaten when cooked usually with yam (Dioscorea rotundata) and palm oil particularly among the Ikwerre ethnic group in Rivers State. The leaves, tender shoots and flowers of Cucurbita maxima Duch ex. Lam serves as vegetable or potherb and is used in soups. They are also used to prepare yam, cocoyam, sweet yam and water yam porridge. The pulp is eaten after the whole fruit had been cooked, it can also be eaten salted, with stew, in soup or as vegetable. It is used to treat inevitable bladder and prostrate complaint namely benign prostrate hyperplasia (BPH). The large leaves shade the soil, for moisture and agricultural purposes.

Cucumeropsis manni Naud. The fruit is edible while seeds, which are very popular are used to thicken soups. The seed coat is removed and the seeds ground for soup and stews. They can also be eaten raw, cooked or fried.

Coccinia barteri (Hooker fill.) keay. In some parts of Niger Delta like in Boki area of Cross River State the leaves together with Zehneria spp are used as vegetable in cooking.

\section{DISCUSSION}

The ethnobotany of plants has been receiving a lot of interest in the last decade against the background of germplasm erosion (as in the emergence of synthetic alternatives) and the need for bioconservation (Cunningham 1994). Such ethnobotanical interest has also made it imperative to better identify potentially useful germplasm of Cucurbit in the Niger Delta areas with respect to the botanical applications in the wake of renewed natural resource management and environmental friendliness.

As has been recorded in the result, Trichosanthes cucumerina occupy a very important place in the diet of some part of the Niger Delta before the advent of its alternative Lycopersicon esculentum, which presently in some area is eroding its cultivation. However from such result, it has been known to have many advantages such as high fruit yield per stand, multiple utilities, disease resistance, and ease of cultivation, better seed production and preservation. Presently also, it is known that the Lycopersicon alternative is really threatening its cultivation (Ndukwu, 2000). The botanical identity of this species seems probably to be that of cultigens selected in antiquity from the species of the genus, which in general have bitter inedible fruits and medicinal attributes. The fruit is eaten young as vegetable. The bright-red pulp around the mature seeds is extracted and used in cooking, like tomato (Lycopersicon esculentum Miller). Immature fruits are boiled and eaten, while mature fruits are used in soups. (Burkill, 1985 and Timothy, 1993). An infusion of the young shoots is mildly aperients. The leaf sap is emetic, while the seeds are anthelmintic and antiperiodic. Lagenaria guineensis has been reported for its use as a depilatory for hides; where as other parts serve medicinal purposes besides its use by the Niger Delta people, Okoli (1984). The fruit and seeds are reportedly used as fish poison by some sections of Southern Nigeria (Okigbo, 1980) and to stupefy fish in some localities (Dalziel, 1937). The sap is used in Ivory Coast as a collyrnim for ophthalmias (Burkill, 1985). Though the usefulness of Momordica charantia to the Niger Delta people has not been fully ascertained, but its potential has been implied for the economic and medical utilization in both animal and humans in various part of the world, as has been noted in Asian continent and some West African countries like Nigeria, Ghana, and Senegal (Ayensu, 1978, Binder et al., 1989). Other countries such as Ivory Coast, Japan, Brazil, and Congo are known for 
their utilization of this species of Cucurbit for various purposes of societal endeavours (Burkill, 1985).

Citrullus vulgaris, besides its application in powdery form to enrich and thicken soups, the seeds may be fermented after soaking in water, boiled and blackened with charcoal and wrapped up in leaves of Newbouldia laevis, Alchornea cordifolia or Musa sapientum to form "ogiri-isi", a food seasoner used in preparing certain kinds of soup or pottage. (Badifu and Ogunsua, 1991). Among the Yorubas in Nigeria the seeds of the local race "bara" are used as part of a decoction, which includes some roots and onions, employed in the treatment of gonorrhea and Leucorrhoea in women and is probably suitable as salad oil (Dalziel, 1937). Other studies have elucidated its ethnobotanical and medicinal importance in various parts of the world like in Senegal, Mauritania, Gabon, and Arabic Nations (Burkill, 1985).

In addition to the ethno-botanical potential of $L$. aegyptiaca to the Niger Delta people, this plant, cultivated, provides edible fruits and leaks. The plant probably has the most diverse use of any of the cultivated Cucurbits. The young fruits of selected non-bitter varieties are eaten as salad or cooked and added to soups. The young leaves are used as a vegetable. The leaves and stems are eaten by sheep, pigs and goats (FAO, 1988). This species of Cucurbit is reported to have tonic and diuretic properties and emetic in larger doses. The fruits contain a bitter purgative principle, Luffein, while the leaves or the expressed juice are applied to sores. An aqueous or alcolic emulsion is reported to be useful as an arthelmintic and the seeds eaten for this purpose with meat in Guinea, (Dalziel, 1937). The spongy fibre is used to make caroil filters, door and bath mats, table mats, fibre pulpboard, shock absorbers in steel helments and armoured vehicles, gloves, hat manufacture, soles of shoes, car-wipers, industrial marine filters, pot holders (FAO, 1988). Similar to the utilization in the Niger Delta, Loofahs are used for filtering water in Ghana, palm-wine in Gabon, and to brush clothes and as cleaning squabs, scrubbers and washing sponges in Jebel Marra (Burkill 1985). They can also be used for stuffing pillows, saddles, and slippers. They can also be used for insulation and are attractive sources for packing materials because of their biodegradability (Timothy, 1993), and economic potential of Loofahs has ensued a growth increase in its domestic production in United States and Asia each year (Davis, 1991). The immature fruits of non-bitter genotypes are eaten fresh like cucumber, cooked as vegetable or used in soups in India and East Asia, although they are inferior to immature $L$. acutangula fruits (Timothy, 1993). In Garbon and Congo, other ethnomedicinal uses have been reported (Burkill, 1985).

The fruit of Cucumis sativus in addition to its Niger Delta utilization is eaten fresh or cooked. Its juice is mildly purgative and diuretic, and is used as vegetable in some countries, or fed to rabbits, guinea pigs and hares. The juice has commercial cosmetic uses to impart a smell and perhaps an emollient effect, thus could be used for soap making and the kernel used for confectionery in India. The juice is known to have ethnomedicinal function as well as pesticidal and insecticidal properties in other parts of the world like Europe, India etc (Burkill, 1985).

Result of the study has shown that L. siceraria is of various varieties and of enormous ethnobotanical application to the people of Niger Delta. It is cultivated chiefly for its dry hard shells of various shapes for uses ranging from container for liquid, grains, floats for fishing net, drinking cup, oat taken, garri processing, ornamental purposes and flute for music etc. on a similar note, some varieties are eaten when young, with the tender fruits serving as curries, while the young shoots and leaves as pot-herbs. Seeds of some varieties are used as matiscatories, while edible oil can be extracted from the seeds of some varieties. A similar assertion has also been made by Dalziel (1937), Ibiok et al, (1991); Okoli, (1984); Purseglove, (1968) and Donald et al (2003). Other uses have been reported in various parts of Nigeria. It has been reported that
L. siceraria are used as basis for attachment of shells, bones, beads and metals to fashion out musical rattles. The use of gourds as receptacles for fish in the Argungu fishing festival in Sokoto State of Nigeria and as containers for fertilizer has also been reported. In northern Nigeria, especially in the Plateau areas, it is common to see Fulani women and young girls hawking "madara" (fresh milk), "nono" (Fermented milk) and/or "kunu" (gruel from guinea corn) in giant beautifully tattooed calabash basing. The medium-sized calabashes, depending on their shape, are used as drinking vessels, ladles, flutes, and other musical instruments (Heiser, 1979). Study had also shown that decorative carvings on the gourds serve ornamental purposes among others (Rubin, 1970). Similar use as in dye stamps used in imprinting designs on cloth in the local dye industry has also been reported. Dalziel (1937) reported that the small ovoid or pear-shaped gourds in graded series and containing cobwebs in different quantities form the resonators of the native xylophone. The "thumb plano"; described by Heiser (1979) as a type of idiophone, is employed in traditional dances in several parts of Nigeria and consists of the rind of a half-gourd covered by a flat piece of wood on which are tied strips of metal of varying length and thickness. Other uses have been reported in various parts of Nigeria (Dalziel 1937, Timothy, 1993). The unparalled variation in fruit shape, size of the different varieties of $L$. siceraria has been reflected in their various purposes in Niger Delta. Telfairea occidentalis is noted for the uses and economic potential of its palatable leaves and nutritious seeds, which are rich in oil used for cooking and soap manufacture (Okoli and Mgbeogu, 1983). The seeds are used for polishing locally made earthenware pots, and the dry shell of the fruit is sometimes used for utensils (Burkill, 1985). Shoot from the female plants can be cooked and eaten (Lucas, 1988). The fruit are large (up to $13 \mathrm{~kg}$ ) and inedible, but the seeds contain up to $50 \%$ protein and can be boiled and eaten or ground into powder for soup. Seeds can also be fermented for several days and eaten as a slurry (Badifu and Ogunsua, 1991).

The Cucurbita is cultivated in northern Nigeria for their fruits, while $C$. moschata is cultivated for both leaves and fruits. Other than its uses as a vegetable and a sauce in Niger Delta, their leaves are also used for wrapping of corn meal and winged termites, cooked and then eaten as a delicacy, mostly by women and children in eastern Nigeria. Cucurbita moschata are widely used with ashes for depilating hides prior to tanning. In Nigeria, it is cultivated in the Northern part of the country for the fruits, while in the Southern part, in a largely unimproved form Ugboguru' is cultivated for both the leaves which constitute an important vegetable and for the fruit, whose pulp is eaten when cooked, the rind been discarded (Okoli, 1984).

The Cucumeropsis mannii has been described as a new crop of immense potential for the tropics (Jaffrey, 1980), a source of oil, protein, carbohydrates and minerals thus may require further investigation. In some parts of eastern Nigeria the leaves of C.mannii are wrapped around fresh corn meal and winged termites, cooked and then eaten as a delicacy mostly by women and children. The fruits and seeds are boiled and eaten together with yam, in some parts of eastern Nigeria, (Okoli, 1984). The flesh of the fruit is edible, and to some areas of the Niger Delta appears to be important than the oily seeds for which the plant is mainly grown. The seeds are edible and oily and used like that of Citrullus vulgaris. The oil is semi-drying, and a good substitute for cottonseed oil and is suitable for soap-manufacture and for illumination. It is used in cooking and can readily be refined into a superior product for table use. It has been noted for its ethnomedicinal uses in nations like Ghana, Sera-Leone, \& Garbon (Burkill, 1985).

Coccinia barteri though may not have presently found its usefulness among the people of Niger Delta but literature has shown that a cold infusion of the plant is used in parts of Nigeria and Western Cameroon for venereal diseases. The powdered dried leaves are applied as a dressing for chancre. Also in Cameroon the juice of the boiled leaves, mixed with a few drops of water is an ear- instillation for earache. While in 
Ghana the content of a fruit mixed with fresh lime juice is applied using a feather to the umbilical cord of a new-born baby tied near the body with a strand of pineapple or plantain fibber, the application is repeated till the cord falls off (Burkill, 1985).

Cucurbita maxima, similar to its utility in the Niger Delta areas the young leaves and shoots including the flowers are used as a potherb, while the Hausa's in Northern Nigeria eat the end-of-season leafy shoots and undeveloped fruits. Similarly the fruit flesh is generally boiled and eaten in pieces or put in stews and soup and in drier climate like in Northern Nigeria and Ghana the pulp is sliced and dried for storage. In other part s of the world like Garbon, Malawi, Senegal, India it has been known for various ethnobotanical and medicinal uses. (Burkill, 1985). It has also been known to provide spectacular material for centerpieces, displays and arrangement for autumn and thanksgiving holidays (Donald et al, 2003).

Citrullus lanatus (Thumb) Mansf; though there has not been any evidence of its cultivation and wild occurrence in the Niger Delta area, except in markets where it is sold certainly for consumption. They serve as source of minerals and vitamins to consumers in the Niger Delta areas. In other parts of Nigeria and some other countries Citrullus lanatus has been identified with numerous ethno-botanical and medicinal potentials. The fruit in near-desert areas where the plant has run wild constitute a valuable source of water. Some other ethnobotanical and medicinal values have been recorded in various parts of Nigeria, Ghana, Senegal, Tanganyica, Lesotho and India (Burkill, 1985).

\section{CONCLUSION}

The present study has revealed the ethnobotanical utility of species of Cucurbit in the Niger Delta area of Nigeria among the various species of Cucurbitaceae. Cucurbits are of ethnobotanical importance in the life and culture of the people of Niger Delta and the entire Nigerian nation. There is an urgent need to promote the development and conservation of these species for the sustenance and general well being of the people and natural heritage- the environment. This could be carried out through hybridization of the perennial and annual species, particularly for the cultivated species and their varieties as a way to the reduction or total eradication of germplasm loss or extinction

\section{AKNOWLEDGEMENT}

I thank the Almighty God who has used the National Biotechnology Development Agency (NABDA) and the United Nations University, Tokyo, Japan, Institute for Natural Resources in Africa (UNU-INRA) to grant me the opportunity to carry out this research.

\section{REFERENCES}

Afolabi, D., 1998. The Nigerian Mangrove system. Third Regional Workshop of the Gulf Guinea Large Marine Ecosystem (GOGLME), Lagos Nigeria. In Alagoa, E. J. (1999). The land and people of Bayelsa State, Central Niger Delta. Onyema Research Publication, Port Harcourt, River State, Nigeria, pp44.

Alagoa, E. J., 1999. The land and people of Bayelsa State, Central Niger Delta. Onyema Research Publication, Port Harcourt, River State, Nigeria, pp 44- 57

Ayensu, E. S., 1978. Medicinal Plants of West Africa: In Okoli, B. E. Wild and cultivated Cucurbits in Nigeria, Econ. Bot. 38(3): 350- 357.

Badifu, G.J.O. and Ogunsua, A. O., 1991. Chemical composition of kernels from some species of cucurbitaceae grown in Nigeria. Plant foods human nutri. 41:35-44.

Binder, R. G., Flath, R. A., and Mon. T. R., 1989. Volatile Components of bittermelon. J. Agr.Food.Chem.37 418-420.

Burkill, H. M., 1985. Useful Plants of West Tropical Africa, Ed.11. Vol.1. Cambridge Univ. Press. Cambridge. Pp 570-605.

Cunningham, A. B., 1994. The role of ethnobotany and customary knowledge in the conservation of plant. In: safeguarding the Genetic Basis of Africa's traditional crops, CTA. The Netherlands / IPERI, Rome. Pp20 25

Dalziel, J. M., 1937. The Useful Plants of West Tropical Africa : In Burkill, H. M. Useful plants of West Tropical African. Ed.11 Vol. 1, Cambridge Univ. Press. Cambridge pp 570-605.

Davies, J. M., 1991. Development of a production system for Luffa Sponge gourds. Hort.Science, 26.708 (Abstr).

Donald, N. M., Amy, M. D., Brain, J. S., 2003. Ornamental and Utilitarian Gourd Evaluation. GCREC- Bradenton Research Report Florida Agricultural Experiment Station. Pp $1-3$.

Edwin-Wosu, N. L., 2005. Studies on the systematics and Distribution of Cucurbits in the Niger Delta Area of Nigeria. NABDA / UNU-INRA.pp 1-66

FAO., 1988. Traditional food plants, food and nutrition. Paper 42 FAO, Rome Italy. Pp 593.

Fubara, D. M. J., Teme, S. C., Mgbeke, J., Gobo, A. E.T. and Abam, T. K. S., 1988. Master plan design of flood and erosion control measures in the Niger Delta IFert Technical Report No.1. pp 1-15

Heiser, C. B. Jr., 1979. The Gourd Book. :In Donald, N.M; Amy, M.D.; Brain, J.S. (2003). Ornamental and Utilitarian Gourd Evaluation. GCREC- Bradenton Research Report Florida Agricultural Experiment Station. Pp $1-3$.

Hutchinson, J. and Dalziel, J. M., 1954. Flora of West Tropical Africa. Crown Agents, London 1, part (1): pp $204-$ 216.

Ibiok, M. N., Ndukwu, B. C and Umoh, N., 1991. Varieties of gourds (Lagenaria siceraria) in Akwa -lbom State. The Nigeria Field 56:115-119.

Jeffrey, C., 1964. Key to the Cucurbitaceae of West Tropical Africa, with a guide to localities and little known species. J.W. African Sci Assoc. 9: 79-97.

Jeffrey. C., 1980. A Review of the Cucurbitaceae. Bot. J. Linn Soc. 81:233-247.

Lucas, E. O., 1988. The potential of leaf vegetable in Nigeria, Outlook Agr. 17: 163 - 168.

Martin, O. J., 1995. Ethnobotany. Chapman and Hall London $288 \mathrm{pp}$.

Ndukwu, B. C., 2000. Conservation of Trichosanthes Linn (snake tornato) Genetic Resources in Nigeria. Nigeria Society for Biological Conservation 7:9-13. 
Okigbo, B. N., 1980. Plants and food in Igbo Culture and Civilization. The Ahiajoku Lecture, Government Printer, Owerri, Nigeria. pp 4 - 46

Okoli, B. E. and Mgbeogu, C. M., 1983. Fluted pumpkin, Telfairea occidentialis Hooker F. West African Vegetable Crop. Econ. Bot. 37:145-149.

Okoli, B. E., 1984. Wild and Cultivated Cucurbits in Nigeria, Econ. Bot. 38(3): 350-357.

Purseglove, J. W., 1968. Tropical Crops Dicotyledons. Vol.1 Longman, London. pp 370 - 374

Rubin, B., 1970. Calabash Decoration in North-Eastern State, Nigeria African Arts 4:20-25.

Teme, S. C., 2001. Environmental peculiarities of the Niger Delta in petroleum exploration operations. In: the National conference of pipeline vandalisation and degradation of the Niger Delta Environment. Rivers State ministry of environment and Natural resources in collaboration with Green House foundation and B. Jean Communication limited Port Harcourt, Rivers State. 27th - 29th Nov. 2001. PP 1-8.

Timothy, J. Ng, 1993. New opportunities in the Cucurbitaceae p.538-546 in; Janick, J. and Simon, J.E. (eds), Wiley, New York. Pp 538 - 546.

Yamaguchi, M., 1983. World Vegetable, production and nutritive values AVI Publishing Company Inc. West Port, Connecticut, In: proceeding of the IPGRI and NRI International workshop on African indigenous vegetables, Limbe Cameroon pp 19 - 109. 